\title{
초전도체의 철기시대
}

DOI: $10.3938 /$ PhiT. 22.005

김용관·김창영·방윤규

Iron Age in Superconductivity

Yeong Kwan KIM, Changyoung KIM and YunKyu BANG

A new high-temperature superconductor based on $\mathrm{Fe}$ was discovered in 2008. Since then, intensive and extensive research has been performed on the subject. In this article, we describe the general features of iron-based superconductors, as well as recent developments in theoretical efforts to understand the microscopic mechanism. We first describe some important aspects of iron-based superconductors. We then discuss the synthesis of various materials, as well as their properties. Finally, we address the most up-to-date theoretical effort to understand the microscopic mechanism based on $\pm s$-wave gap symmetry.

\section{철 기반 고온 초전도체 소개}

\section{Introduction to iron-based superconductors}

초전도 현상은 극저온에서 고체의 저항이 0이 되는 현상을 말한다. 1911년 Onnes에 의해 처음 발견되었으며 30년 뒤 Bardeen, Cooper, Schrieffer에 의해 발현 원리가 규명되었다. $\mathrm{BCS}$ 이론이라 불리는 이 이론은 고체 내 두 전자가 격자 떨림 에 의해 묶여 하나의 쿠퍼쌍(Cooper pair)을 형성하고 이들이 저항이 없이 전류를 흐르게 한다고 말하고 있다. 또한 $\mathrm{BCS}$ 이 론은 초전도 현상을 설명하는 동시에 초전도 임계 온도 $\left(T_{\mathrm{C}}\right)$ 를 한계 짓는데 이는 대략 $40 \mathrm{~K}$ 으로 $\mathrm{BCS}$ limit으로 알려져 있다.

하지만 1987년 이 BCS limit를 뛰어넘어 초전도 현상을 보이

\section{저자약력}

김용관 연구원은 2008년 연세대학교 물리학과를 졸업하고, 현재 연세대학교 물리학과 박사과정에 재학 중이며, 철 기반 초전도체 연구를 수행하고 있다. (myrni@yonsei.ac.kr)

김창영 교수는 스탠포드 대학교 응용 물리학 박사(1995)로서 스탠포드 방사 광 가속기 연구소 연구원을 거쳐(1995-2001) 현재 연세대학교 물리학과 교 수(2001-현재)로 재직 중이다. (changyoung@yonsei.ac.kr)

방윤규 교수는 미국 뉴저지주립대학(Rutgers) 이학박사(1991)로서 MaxPlanck Inst, Stuttgart, ICTP, Trieste 등지에서 포스트닥터 연구원을 거쳐 1995년부터 전남대학교 물리학과에서 교수로 재직 중이다. (ykbang@jnu.ac.kr)
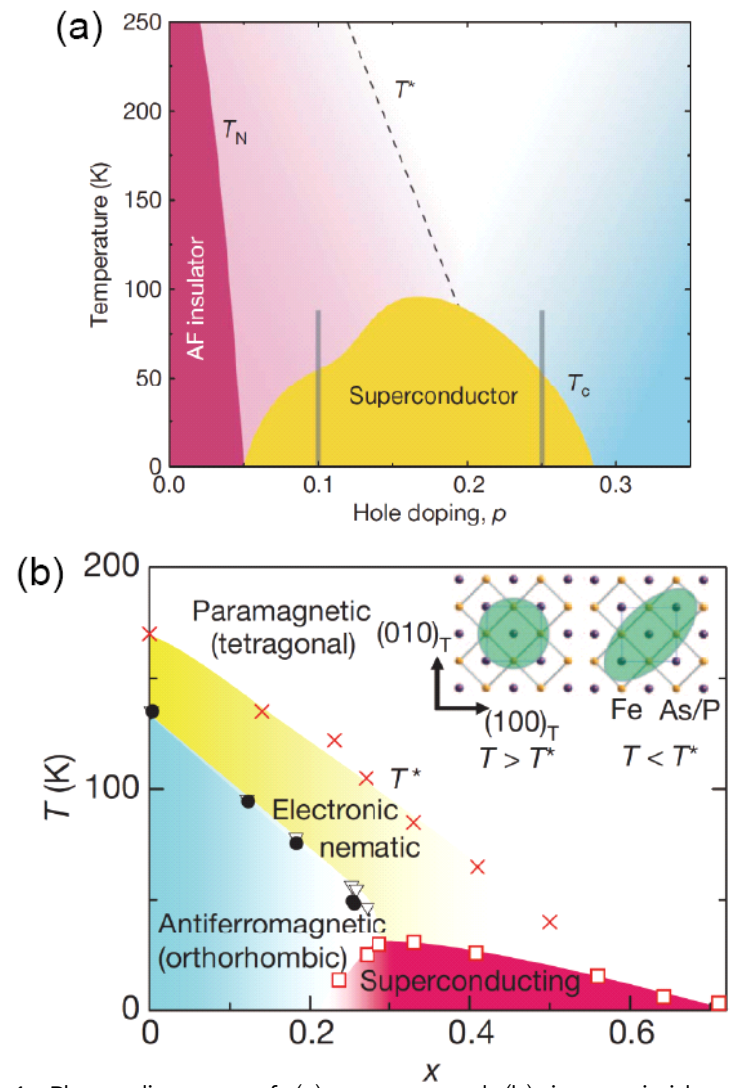

Fig. 1. Phase diagrams of (a) cuprate and (b) iron pnictide superconductors. ${ }^{[2]}$ ( $T^{*}$ is the transition temperature for the nematic phase in iron pnictides and cuprates.)

는 물질이 발견되었다. 구리 산화물계 초전도체가 그것인데 최 대 임계 온도 $163 \mathrm{~K}$ 를 보여 기존의 $\mathrm{BCS}$ 로는 설명이 불가능하 다. 이런 $\mathrm{BCS}$ 이론으로 설명되어지지 못하는 초전도현상을 따 로 고온초전도현상 혹은 물질이라고 한다. 고온초전도현상의 원 리를 규명하기 위해 1987년 발견 이후부터 수많은 연구가 진행 되어 왔지만 메커니즘은 아직까지도 밝혀지지 않은 채 남아있다.

2008년, 오랜 시간의 지난한 과정을 통해 고온초전도현상 연 구가 그 추진력을 잃어가고 있을 때, 새로운 물질에서 고온초전 도 현상이 나타났다. 이번엔 철을 기반으로 하는 물질에서 고온 초전도현상이 나타났다.[1] 철 기반 초전도체의 발견은 고온초전 도현상의 새로운 활력소가 되었고 수많은 연구진들이 다시 고온

\section{REFERENCES}

[1] Yoichi Kamihara et al., J. Am. Chem. Soc. 130, 3296 (2008).

[2] S. Kasahara et al., Nature 486, 382 (2012). 


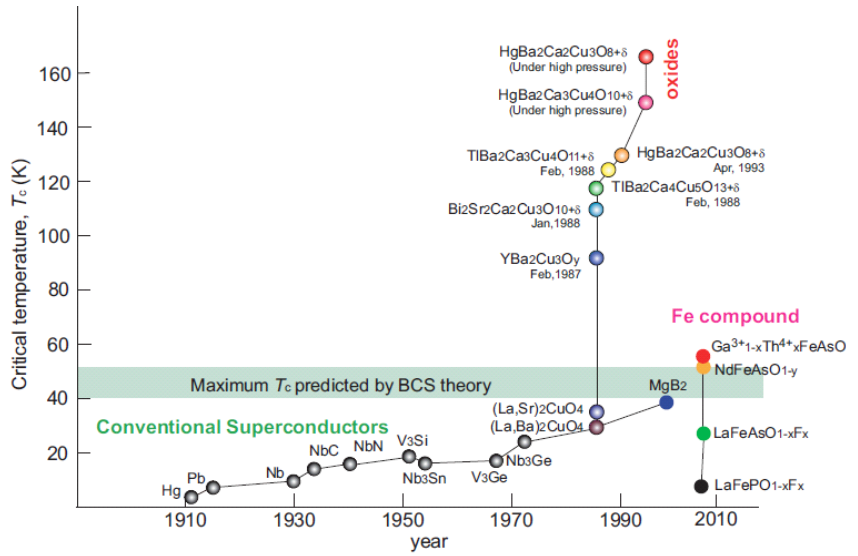

Fig. 2. Time table of discoveries of various superconductors.

초전도현상을 규명하기 위해 이 새로운 분야에 뛰어 들었다.

철 기반 초전도체 발견의 의의는 단순히 새로운 고온 초전도 물질이 추가된 것에 그치지 않는다. 이 신물질의 발견으로 고온 초전도현상을 이해할 수 있는 새로운 전기가 열렸다. 기존의 $\mathrm{BCS}$ 이론에 의하면 두 개의 전자가 모여 쿠퍼쌍을 이룰 때, 전 자의 스핀은 반대가 되어 전체 쿠퍼쌍의 스핀은 0 이 되게 된다. 이 때문에 초전도 현상은 자성물질에서는 발현되기 힘들 것이라 는 것이 학계의 일반적인 통념이었다. 하지만 대표적인 자성물 질인 철 기반 물질에서 초전도 현상이 발견됨으로써 이런 통념 이 깨어지게 되었다. 이로 인해 격자 떨림이 아닌 자성요동 (spin fluctuation)이 새로이 고온 초전도현상을 발현시킬 수 있 는 요인으로 다시 한번 주목 받게 되었다.

실제로 자성요동은 구리 산화물계 고온초전도체 연구에서도 먼저 주목을 받았었다. 구리 산화물계의 고온 초전도 현상은 반 강자성 현상이 전하 도핑이나 압력 등의 외부요인에 의해서 약 해질 때 나타난다. 고온초전도 현상과 반강자성 현상과의 관계 는 상도표에서 확인할 수 있다(그림 1(a)). 반강자성의 양자 상 전이 점에서 최대 임계온도를 가짐으로써 반강자성의 들뜬 상 태, 자성요동의 역할이 주목 받게 되었다. 하지만 앞서 말한 통 념에 의해 자성요동 역할론은 쉽게 받아들여지지 못하고 있었 다.

발견된 철 기반 초전도체는 구리 산화물계 물질과 같이 반강 자성 현상과 고온 초전도 현상을 보인다. 그림 $1(\mathrm{~b})$ 의 상도표를 보면 두 물질의 상도표가 같은 것을 확인할 수 있다. 새로이 발 견된 고온 초전도 현상 역시 반강자성과 같이 발현되며 기반물 질이 자성물질인 것으로 말미암아 자성요동이 고온초전도현상의 매개체로 주목 받게 되어 고온초전도 현상 연구의 방향이 바뀌 게 되는 계기가 되었다.

더 나아가 철 기반 초전도체는 고온 초전도 연구에의 전혀 새로운 가능성을 제시하는데 이는 철 기반 초전도체의 고유성에 기인한다. 구리 기반 초전도체와는 다르게 철 기반 초전도체의

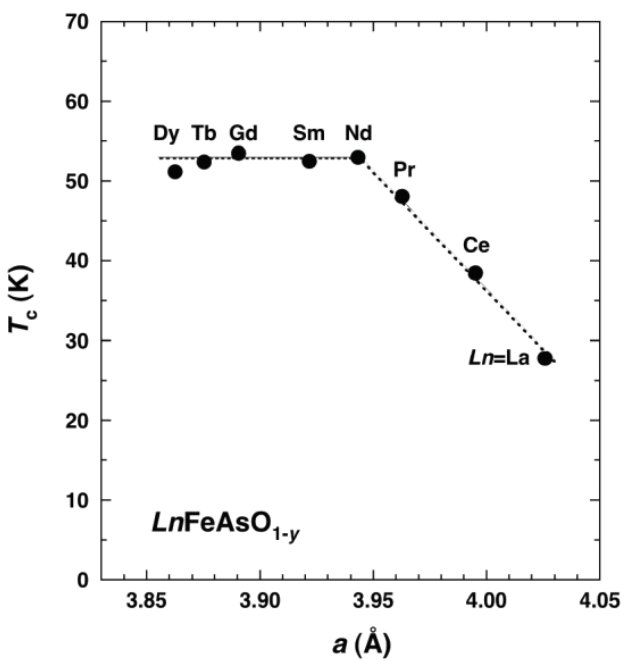

Fig. 3. Critical temperatures of various 1111 -phases. ${ }^{[5]}$

전자구조는 다중 오비탈에 의한 다중 밴드를 갖는다. 이러한 다 중 오비탈-밴드구조는 철 기반 초전도체에서 나타나는 물리현 상, 반강자성과 고온 초전도현상에의 오비탈 자유도의 역할을 암시하게 된다. 실제로 철 기반 초전도체에서는 망간 산화물에 서와 같이 오비탈 정렬 현상이 나타난다는 것이 최근에 밝혀졌 다. ${ }^{[3]}$ 이러한 오비탈 정렬의 들뜬 상태 혹은 집단 모드가 고온 초전도현상을 매개할 수 있을 것이라는 이론적 모델도 제안되었 다. ${ }^{[4]}$ 기존에 전혀 고려되지 않았던 오비탈 자유도의 역할이 대 두된 것이다.

이처럼 새로운 철 기반 초전도체의 발견으로 인해 고온초전도 연구는 새로운 국면으로 접어들게 되어, 고온 초전도 연구가 청 동기(구리 기반 초전도체) 시대에서 철기(철 기반 초전도체) 시 대로 넘어간 것에 비유될 수 있다. 최초의 발견 이후로 약 5년 동안 수천 편의 논문이 발표되었으며 기존의 구리 기반 초전도 체 연구 과정에서 얻어진 이론적/실험적 연구 결과가 접목되어 많은 철기반 고온 초전도체가 만들어졌다(그림 2). 지금까지 다 섯 가지 물질 군의 철 기반 초전도체가 발견되었으며 이들의 기본적인 물성은 밝혀져 있으며 세부적 이슈에 대한 합의에도 도달해있다. 기초학문적인 측면에서 보면 이제 철 기반 초전도 체 연구는 고온 초전도 현상의 근본을 밝히는 것이 남아있다. 고온초전도 질서변수의 대칭성, 고온 초전도의 매개체 및 미시 원리가 그것이다. 자성 요동과 추가로 오비탈 요동이 철 기반 초전도체의 고온 초전도 현상을 이해함에 있어 결정적 역할을 할 것으로 기대된다. 나아가 구리산화물을 포함한 고온초전도 현상의 일반론적 메커니즘 규명이 가능할 것으로 기대된다. 초

\section{REFERENCES}

[3] Y. K. Kim et al., arXiv:1112.2243.

[4] Seiichiro Onari et al., Phys. Rev. B 82, 144510 (2010).

[5] Kiichi Miyazawa et al., J. Phys. Soc. Jpn. 78, 034712 (2008). 
(a)

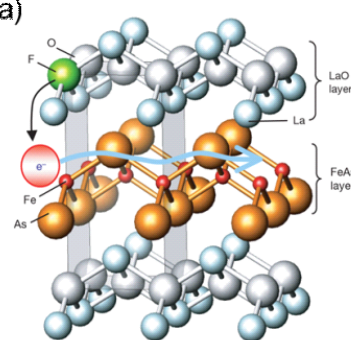

(c)

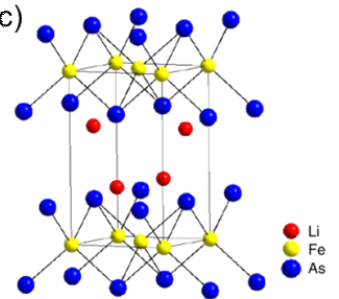

(b)

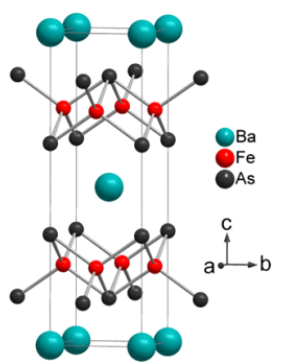

(d)

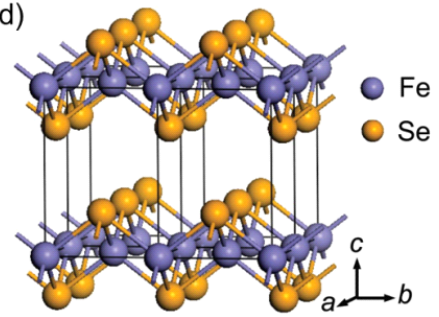

Fig. 4. Crystal structures of (a) 1111-phase, ${ }^{[6]}$ (b) 122-phase, ${ }^{[7]}$ (c) 111-phase, ${ }^{[8]}$ and (d) 11-phase. ${ }^{[9]}$

전도 연구에서의 새로운 시대의 시작이라 할 수 있다.

\section{다양한 철기반 초전도 물질의 합성 및 특성}

Synthesis and properties of various materials

2008년 최초로 합성된 철 기반 초전도체는 $\mathrm{La}\left(\mathrm{O}_{1-\mathrm{x}} \mathrm{F}_{\mathrm{x}}\right) \mathrm{FeAs}$ 로 초전도 임계온도는 $26 \mathrm{~K}$ 이다. 최초의 발견 이후로 임계온도는 빠르게 증가하여 최대 $56 \mathrm{~K}$ 를 기록하였다. 이와 같은 빠른 증 가는 이전 구리 산화물계 초전도체에서 얻어진 결과를 토대로 이루어졌다. 기존 구리 산화물계 초전도체 물질 연구에서 알려 진 바에 의하면 격자 구조가 2차원에 가까워질수록 $T_{\mathrm{C}}$ 가 올라 간다. 같은 방식으로 란타늄보다 크기가 큰 다른 란탄 계열의 원자를 치환함으로써 임계온도를 상승시킬 수 있었다. 그림 3은 다양한 란탄계 원소로 만들어진 LnOFeAs의 임계온도를 보여준 다. ${ }^{[5]}$ 이런 란탄계열 원소가 다른 여러 물질들을 묶어 1111phase라 한다.

이후 Rotter에 의해 새로이 $\mathrm{BaFe}_{2} \mathrm{As}_{2}$ 가 추가로 철 기반 초전 도체로써 제안되었다. ${ }^{[7]} \mathrm{BaFe}_{2} \mathrm{As}_{2}$ 는 1111-phase에서 보이는 $\mathrm{FeAs}$ 층을 갖고 있어(그림 $4(\mathrm{~b}))$ 초전도 현상이 나타날 것으로 예상되었고 실제로 $\mathrm{Ba}$ 를 $\mathrm{K}$ 으로 치환하였을 경우 임계 온도 38 $\mathrm{K}$ 의 초전도 현상이 발현되었다. 이후 비슷한 $\mathrm{CaFe}_{2} \mathrm{As}_{2}$ 및 $\mathrm{SrFe}_{2} \mathrm{~A}_{2}$ 에서도 초전도 현상이 추가적으로 발견되었으며 치환 원소도 $\mathrm{Co}, \mathrm{Ni}, \mathrm{Ru}, \mathrm{P}$ 등 다양하게 발견되었다. 이들 물질을 통틀어 122-phase라 한다. 122-phase는 다른 phase에 비해 결정 성장이 용이하며 다양한 치환 물질 군이 존재하여 대다수 의 철 기반 초전도체 연구가 122-phase 물질을 사용하여 이루 어져 왔다.
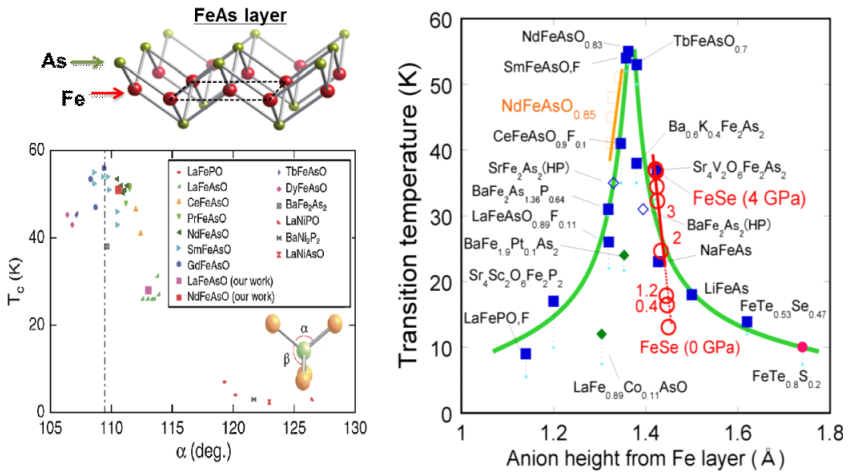

Fig. 5. Relationship between the critical temperature and crystal structure (bonding angle or anion height). ${ }^{[11,12]}$

122-phase의 발견 이후 $\mathrm{FeAs}$ 층의 중요성이 부각되었으며 $\mathrm{FeAs}$ 층을 갖는 다른 물질들을 찾기 시작하였다. 이로 인해 새 로이 세 가지 phase가 철 기반 초전도 물질 군에 추가되게 된 다. 1111- 및 122-phase 내의 FeAs층은 물질 내에서 각각 $(\mathrm{LnO})^{+}(\mathrm{FeAs})^{-}, \mathrm{Ba}^{2+}(\mathrm{FeAs})_{2}{ }^{-}$로 전자 하나를 추가로 받게 된다(그 림 4(a)). 새로운 물질들은 이러한 전하분포를 이룰 수 있는 물 질로 탐색되었으며 111-phase(그림 4(c)) 및 11-phase(그림 4(d))라 명명된 물질이 추가될 수 있었다. 111-phase 물질은 $\mathrm{LiFeAs}$ 와 $\mathrm{NaFeAs}$ 로 각각 임계온도 $18 \mathrm{~K}$ 와 $7 \mathrm{~K}$ 을 갖는다. 11-phase는 As 대신에 칼코겐, 산소족 원소 중 $\mathrm{Se}$ 과 $\mathrm{Te}$ 이 $\mathrm{Fe}$ 과 결합하여 $\mathrm{FeSe}$ 혹은 $\mathrm{FeTe}$ 층을 이룬다. 11-phase는 $\mathrm{FeSe}$ 혹 은 $\mathrm{FeTe}$ 층으로만 이루어져 있으며 $\mathrm{Se}$ 및 $\mathrm{Te}$ 은 $\mathrm{As}$ 보다 전자를 하나 더 가지므로 $(\mathrm{FeAs})^{-}$의 전하분포를 만족한다.

마지막으로 $\mathrm{FeAs}$ 층 사이에 산화물 층을 삽입한 복잡한 화학 식의 물질 군이 발견되었으며 이는 역시 구리 산화물계 연구 결과에서 얻어진 2차원 격자구조에서의 임계온도 상승을 고려 하여 시도되었다. 대표적으로 바나듐 산화물 층을 삽입한 $\mathrm{Sr}_{2} \mathrm{VO}_{3} \mathrm{FeAs}$ 가 있다. 이 물질은 임계온도 $37 \mathrm{~K}^{[10]}$ 을 갖는다.

위와 같이 다섯 가지의 군으로 대표되는 수많은 종류의 철 기반 초전도체들이 발견되었다. 각각의 물질은 초전도 임계 온 도도 다를 뿐만 아니라 세부적으로 다른 물성들을 보이기도 한 다. 그렇다면 전체 철 기반 초전도 물질을 아우르는 일반적인 특성이 있을까? 만일 없다면 철 기반 초전도 물질 군은 각각 개별적, 독립적으로 이해되어야 할 것이다.

다행히 모든 철 기반 초전도체의 물질들은 특이한 격자구조 의존성을 보인다. 각 물질 내의 $\mathrm{FeAs}$ 층의 As-Fe-As 원자간 결

\section{REFERENCES}

[6] H. Takahashi et al., Nature 453, 376 (2008).

[7] Marianne Rotter et al., Phys. Rev. B 78, 020503(R) (2008).

[8] X. C. Wang et al., Solid State Commun. 148, 538 (2008).

[9] F.-C. Hsu et al., Proc. Natl. Acad. Sci. USA 105, 14262 (2008).

[10] Xiyu Zhu et al., Phys. Rev. B 79, 220512® (2010). 
합각에 따라 임계온도를 표시해보면 이 특이한 의존성을 확인할 수 있는데 (그림 5), 특정한 결합각을 갖는 물질이 최대의 임계 온도를 보이는 것을 알 수 있다. ${ }^{[1]}$ 또한 이 특이한 의존성은 $\mathrm{As}$ 혹은 $\mathrm{Se}$ 원자의 $\mathrm{Fe}$ 층에서부터의 높이로 임계온도를 표시할 경우에도 나타난다. ${ }^{[12]}$ 이런 특이한 경향성은 격자구조와 임계온 도 간의 강한 상관관계를 암시해주며 모든 철 기반 초전도 물 질에서 나타나는 초전도 현상이 하나의 메커니즘으로 설명될 수 있음을 시사해 준다.

그럼에도 불구하고 지금까지의 연구결과는 이런 철 기반 초전 도체에서 발현되는 고온 초전도현상에 일반적으로 적용될 수 있 는 원리를 제시하고 있지는 못하다. 2008년 발견 이후, 수많은 연구진에 의해 천 편이 넘는 연구 결과들이 보고되었지만 대부 분의 초기 연구는 물질의 발견 및 비저항, 열전도율 등의 기본 물성 측정에 그쳤다. 많은 숫자의 물질 군으로 인하여 대다수 의 연구가 독립된 연구진에 의해 개별적으로 진행되어 초전도 현상 및 자성현상에 일반적으로 적용될 수 있는 이해는 아직까 지는 이루어지고 있지 않다. 하지만 철 기반 초전도체의 발견 이 2008년임을 상기했을 때 5년간의 짧은 연구기간에 수많은 물질이 발견되었고 대부분의 기본 물성 측정 및 세부적인 이슈 에 대한 합의가 이루어진 것은 고무적인 결과라 할 수 있다. 이 는 수많은 연구진의 노력의 결과이고 앞서 말했듯이 수십 년에 걸쳐 쌓여진 구리 산화물계 연구 노하우 및 실험장비의 발전이 있었기에 가능했다.

이제는 우리에게는 비밀을 품고 있는 수많은 퍼즐조각을 눈앞 에 두고 있다. 이제 철 기반 초전도체 연구는 이러한 퍼즐 조작 을 맞춰 큰 그림, 초전도 현상의 미시원리를 그려나갈 때이다.

\section{철 기반 초전도의 이론}

\section{$d$-wave superconductivity universality}

2008년 $\mathrm{La}\left(\mathrm{O}_{1-\mathrm{x}} \mathrm{F}_{\mathrm{x}}\right) \mathrm{FeAs}$ 초전도 물질의 발견으로 시작된 철-기 반 초전도체에 관한 연구는 가히 폭발적이었다고 말할 수 있다. 이유는 이미 앞 장에서 설명한 대로 지난 25년간 구리 기반 고 온 초전도를 연구하면서 어마 어마한 양의 실험 및 이론 연구의 경험과 know-how들이 축적되어 있는 상태였기 때문이다. 이러 한 지식들이 워낙 어려운 문제인(이 문제가 어려운 이유는 실질 적인 문제와 심리적인 문제가 뒤섞여 있다) 구리-기반 고온 초전 도체 연구에서는 별로 힘을 발휘하지 못하다가, 유사하지만 보다 단순한(이것 또한 보는 관점에 따라서 다를 수 있지만) 물질인 철 기반 초전도 물질을 만나서 마치 연습문제 풀듯이 (왜냐하면 구리-기반 초전도체를 대상으로 이미 다 해본 메뉴들이었으므로) 세계 각국의 연구실에서 논문들을 쏟아내게 되었다. 이러한 사정 은 실험 연구뿐만 아니라 이론 연구에서도 마찬가지 상황이었다.
본 장에서는 간략하게 지난 5 년간 진행되어온 철-기반 초전도체 의 초전도 이론 연구와 구리-기반 고온 초전도체의 초전도 이론 과의 관계, 그리고 남은 문제점 등에 관하여 논의하고자 한다.

\section{1. 철-기반 초전도체의 초전도 갭 대칭성: $\pm s$-wave pairing state}

최고 임계온도 약 $55 \mathrm{~K}(\mathrm{SmFeAs}(\mathrm{FO}))$ 의 고온 초전도체이지 만, 철-기반 초전도체와 구리-기반 고온 초전도체의 가장 큰 차 이점은 소위 undoped 상태인 모 물질에서 Mott 부도체가 아닌 금속이라는 사실이다. 이 점은 구리-기반 초전도와 철-기반 초 전도체가 모두 구리 또는 철 이온의 $d$-orbital 전자가 전도띠를 이루는 강상관계 물질이지만, 상대적으로 철-기반 초전도 물질 의 강상관계가 훨씬 약하다는 것을 의미한다. 하지만, 유사점도 있는데, 두 물질 군이 모두 $d$-orbital 전자들이 지배하는 물질 이며, 각각 철 이온과 구리 이온의 실 공간의 ab-plane 상에서 의 배열이 직각 격자를 형성하는 같은 결정구조 때문에, 두 물 질 모두 모 물질에서 반강자성 질서(antiferromagnetic longrange order, $\mathrm{AFM}$ )를 보인다. 그림 1의 상도표에서 보듯이, 전 자이든 홀(hole)이든 carriers를 도핑하면, 반강자성 질서가 약화 되면서 질서가 깨지는 지점 부근에서부터 초전도 상전이가 일어 남을 볼 수 있다. 이러한, 반강자성 질서의 약화와 초전도 상전 이의 나타남은 구리-기반 고온초전도체, 철-기반 초전도체뿐만 아니라, 임계온도가 극도로 낮은 $(1 \mathrm{mK}$ 에서 $1 \mathrm{~K}$ 정도 $)$ 중페르미온 (heavy fermion) 초전도 물질에서도 공통적으로 나타나는 보편 적인 현상이다. 이 공통점은 뒤에 논의하게 될 $d$-wave superconductivity universality의 주요한 근거이다.

따라서 2008년 철-기반 초전도체가 발표되자마자, 수 주일 사이에 몇몇 이론가들이 철-기반 초전도체에 관한 이론을 발표 하였고, 지금까지도 이 초기이론이 큰 수정 없이 올바른 이론으 로 받아들여지고 있다. I. Mazin ${ }^{[13]}$ 과 K. Kuroki ${ }^{[14]}$ 의 논문이 가 장 빠른 이론논문이었는데, 기본적인 아이디어는 다음과 같다. 먼저, 강상관계를 무시한 표준적인 $\mathrm{LDA}$ 밴드계산 결과 대부분 의 철-기반 초전도체는 그림 6 에 보이는 것과 같은 구조의 Fermi Surface $(\mathrm{FS})$ 를 지닌다. 즉, Brillouin Zone 내에 두 그룹 의 서로 떨어져 있는 FS가 형성되는데, 그 떨어져 있는 거리가 - 역 공간에서의 거리 - 대략 $(\pi, \pi)$ 정도 떨어져 있다. 이러한 FS의 구조는 소위, nesting이라고 불리는 조건을 만족하는데,

\section{REFERENCES}

[11] Chul-Ho Lee et al., J. Phys. Soc. Jpn. 77, 083704 (2008).

[12] Y. Mizuguhci et al., Supercond. Sci. Technol. 23, 054013 (2010).

[13] Mazin I. I., Singh D. J., Johannes M. D. and Du M. H., Phys. Rev. Lett. 101, 057003 (2008)

[14] K. Kuroki et al.., Phys. Rev. Lett. 101, 087004 (2008). 


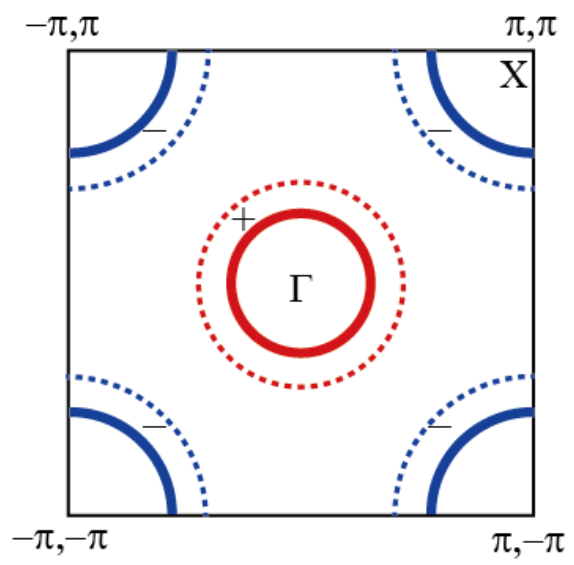

Fig. 6. Simplified two band Fermi surfaces of iron pnictides (red/ blue solid lines) and $\pm s$-wave gap solution (red/blue dashed lines). ${ }^{[15]}$

이 조건이 만족될 경우, $\mathrm{FS}$ 저 에너지 전자들 간의 여기가 특 히, 운동량 전이 $Q=(\pi, \pi)$ 정도의 차이가 날 경우 매우 왕성 하게 일어남을 뜻한다. 즉, 스핀 감수율 $\chi(\omega \approx 0, Q)$ 가 발산하 게 된다. 이런 조건이 만족되면, 따라서 전자의 스핀들이 $(\pi, \pi)$ 정렬을 하게 되며, 이를 반강자성 정렬이라고 하고, 실제로 대 부분의 철-기반 초전도 물질이 도핑이 되지 않았을 경우 반강 자성 정렬을 한다 (그림 1). 다만, 철-기반 초전도체는 반강자성 정렬을 하더라도 부도체가 되지 않고 금속상태로 남아있는데, 이러한 이유로 철-기반 초전도체의 반강자성 정렬을 itinerant $\mathrm{SDW}$ (spin-density wave) 정렬이라고 한다. 이제 모 물질에 도 핑을 하면 반강자성 정렬의 긴 범위 정렬은 깨어지지만 상당한 도핑 범위까지 스핀 감수율 $\chi(\omega \approx 0, Q)$ 가 매우 큰 값을 유지 하게 될 것이다. 이는 전자들간에 강한 반강자성 요동이 교환 된다는 의미이며, 이제 가장 간단한 그리고 표준적인 초전도 이론인 $\mathrm{BCS}$ 이론을 일반화하여, 주어진 $\mathrm{FS}$ 의 전도전자들과 강 한 반강자성 요동을 결합한 초전도 갭 공식을 다음과 같이 쓸 수 있다. ${ }^{[14]}$

$$
\begin{array}{r}
\Delta_{h}(k)=-\sum_{k^{\prime}}\left[V_{h h}\left(k, k^{\prime}\right) \Delta_{h}\left(k^{\prime}\right) \chi_{h}\left(k^{\prime}\right)\right. \\
\left.+V_{h e}\left(k, k^{\prime}\right) \Delta_{e}\left(k^{\prime}\right) \chi_{e}\left(k^{\prime}\right)\right] \\
\begin{aligned}
\Delta_{e}(k)=-\sum_{k^{\prime}} & {\left[V_{e h}\left(k, k^{\prime}\right) \Delta_{h}\left(k^{\prime}\right) \chi_{h}\left(k^{\prime}\right)\right.} \\
& \left.+V_{e e}\left(k, k^{\prime}\right) \Delta_{e}\left(k^{\prime}\right) \chi_{e}\left(k^{\prime}\right)\right]
\end{aligned}
\end{array}
$$

위 방정식에서 두 개의 갭, $\Delta_{h}, \Delta_{e}$ 를 가정한 이유는 그림 6에 서 보듯이 두 개의 $\mathrm{FS}$ 를 가정했기 때문이며, $V_{(h, e)}$ 등은 정공 밴드, 전자밴드 사이의 쌍 상호작용이며, 운동량 공간에서 이들 $V_{(h, e)}\left(k, k^{\prime}\right)$ 은 항상 positive(repulsive)이다. 이 반발 작용의 미 시원리는 앞에 설명한 반강자성 요동이며, 위 방정식에 사용한 쌍 포텐셜의 모양은 다음과 같다. $\pm s$-wave $=d$-wave

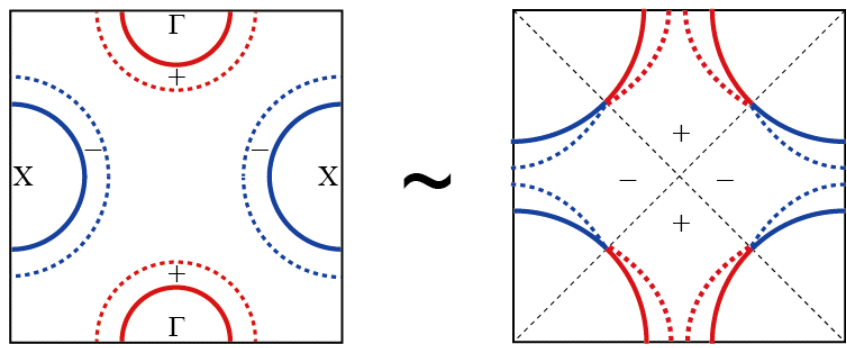

Fig. 7. Topological equivalence between $\pm s$-wave and $d$ wave gaps: In each case, strong repulsive interaction $V_{(h, e)}(Q)(Q=(\pi, \pi))$ connects the "+" and "-" parts of the superconducting gap.

$$
V\left(k, k^{\prime}\right)=V_{M} \frac{\kappa^{2}}{\left|\left(\vec{k}-\vec{k}^{\prime}\right)-\vec{Q}\right|^{2}+\kappa^{2}}
$$

위의 결합된 갭 공식을 풀면, 그림 6에 보이는 소위, signchanging-wave 갭 solution( $\pm s$-wave 갭)을 얻게 된다. 이 $\pm s$ -wave 갭의 특성은 두 갭 사이의 부호가 서로 다르다는 것을 제외하면, 각 밴드에 대하여는 full $s$-wave 갭과 같은 특성을 가진다. 그러나 대부분의 실험 데이터를 이해하려면 불순물 충 돌 효과 등을 고려해야 하는데, 이때 두 갭 사이의 \pm 부호가 매우 특별한 역할을 하기 때문에, 기대했던 단순한 full $s$-wave 갭 특성이 근본적으로 바뀌게 된다. 그러나 무엇보다 중요한 사 실은 그림 6 의 $\pm s$-wave 갭은 반강자성 요동에 의한 쌍결합의 관점에서 볼 때, 구리-기반 고온 초전도체의 갭 대칭성인 $d$ -wave 갭과 정확히 같은 원리에 의한 것이라는 점이다. 쌍 결 합의 원리는 같지만, 두 물질은 FS의 구조가 다르다는 -- 한 경 우는 두 개의 작은 $\mathrm{FS}$ 가 서로 떨어져 있고, 다른 경우는 하나 의 큰 FS가 Brillouin zone을 따라서 대부분 연결되어 있다 -단순한 차이 때문에 결과적으로 매우 다른 초전도 갭을 갖게 된 것이다. 이 원리는 그림 7 에서 두 개의 갭을 비교해 놓은 것을 보면 쉽게 알 수 있다.

\section{2. $\pm s$-wave state의 초전도 특성들}

쌍 결합의 원리는 같지만, 어쨌든 $\pm s$-wave 갭은 $d$-wave 갭 과 열역학적 특성이 전혀 다른 초전도 상태이다. 특히, 중요한 차이는 $\pm s$-wave 갭은 nodal point(s)가 없는 등방성 $s$-wave 갭이나, $d$-wave 갭의 경우에는 nodal point(s)가 존재한다는 것 인데, 이는 여러 가지 열역학적 초전도 특성 - 예를 들면, 비 열, 자기장 침투 깊이, 핵자기공명 실험 등의 온도 의존성 - 에 서 매우 중요한 차이점을 만들어 낸다. 2008년에 제시된 철-기

\section{REFERENCES}

[15] Y. Bang and H. Y. Choi, Phys. Rev. B 78, 134523 (2008). 

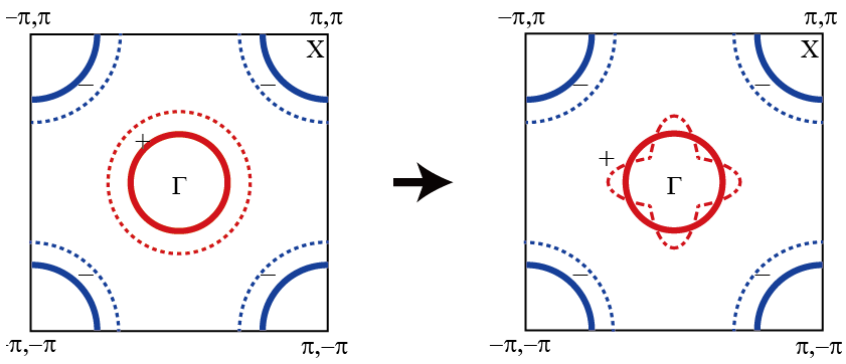

Fig. 8. Schematic of continuous evolution from $\pm s$-wave gap to nodal gap. Gap symmetry is kept unchanged during the evolution.

반 초전도체의 이론인 $\pm s$-wave 갭 이론은 꽤 설득력이 있는 이론이었고, 초기의 실험들이 fully opened $s$-wave 갭 특성을 관측함으로써 - 자기장 침투 깊이, 각분해능 광전자 분석 실험, 터널링 실험 등등 - 실험적으로 이론의 정당성이 상당히 확인 되는 듯하였다. 그러나 곧 이어 발표된 실험들이 nodal-갭 초전 도의 특성들을 보여주면서 실험적 도전을 받게 되었다. 그 주요 한 도전을 열거하면 다음과 같다.

(1) NMR 1/T1 relaxation rate $\sim T^{3}$ 또는 $T^{\alpha}(\alpha=3-5)$.

(2) 자기장 침투 깊이 $\lambda(T) \sim T^{\beta}(\beta=2-3)$.

(3) Thermal conductivity $\kappa(H)$ 또는 비열 $C / T(H)$ 의 자기 장 의존성: $\kappa(H), C / T(H) \sim H^{\delta}(\delta=0.5-1)$.

간단히 생각해서, $\pm s$-wave 갭 상태는 초전도 상태에서 위에 열거한 온도 또는 자기장 의존성이 지수함수적으로 flat하여야 한다. 위에 열거한 온도 또는 자기장의 멱승 관계(power law)는 구리-기반 고온초전도체를 연구하면서 잘 알려진 nodal 갭 초전 도의 특성들이다. 이러한 심각한 모순적 상황은 $\pm s$-wave 갭 상태의 불순물 충돌에 대한 특이한 반응과, ${ }^{[16]}$ 또한 다중 갭 $s$ -wave 초전도체( $\pm s$-wave 갭이 이에 해당함)의 특이한 Volovik 효과 ${ }^{[17}$ 에 대한 이론적 연구에 의하여, 매우 자연스러운 $\pm s$-wave 갭 초전도체의 거동임이 밝혀졌다. 따라서 $\pm s$-wave 갭 모델을 위협하던 실험사실들이, 이론적 연구에 의하여 $\pm s$-wave 갭 모 델을 강화하는 증거로 바뀌어 버린 것이다. 이 글을 쓰는 현재 로써는 지금까지 발견된 30 여 종이 넘는 철-기반 초전도체의 거의 대부분은 $\pm s$-wave 갭 모델에 매우 잘 부합되는 특성들 을 보여준다. 다만, 아직도 논란이 되는 몇 개의 예외가 있는데, $\mathrm{LaFePO}, \mathrm{BaFe}_{2}\left(\mathrm{As}_{1-\mathrm{x}} \mathrm{P}_{\mathrm{x}}\right)_{2}, \mathrm{KFe}_{2} \mathrm{As}_{2}, \mathrm{LiFeP}$ 등은 실험연구자들에 의해서 꾸준히 nodal 갭초전도 또는 $d$-wave 초전도 상태라고 주장되고 있다. 하지만, 필자의 최근의 분석에 의하면, ${ }^{[18]}$ 이들 중 $\mathrm{LaFePO}$ 와 $\mathrm{BaFe}_{2}\left(\mathrm{As}_{1-\mathrm{x}} \mathrm{P}_{\mathrm{x}}\right)_{2}$ 은 오히려 $\pm s$-wave 갭 모델에 잘 부합되며, nodal 갭초전도일 가능성은 없다고 판명되었다. 다만, $\mathrm{KFe}_{2} \mathrm{As}_{2}$ 와 LiFeP은 nodal 갭 초전도일 가능성이 있다고 생각된 다. 그러나 이들 두 물질이 nodal 갭 초전도체라고 하더라도,

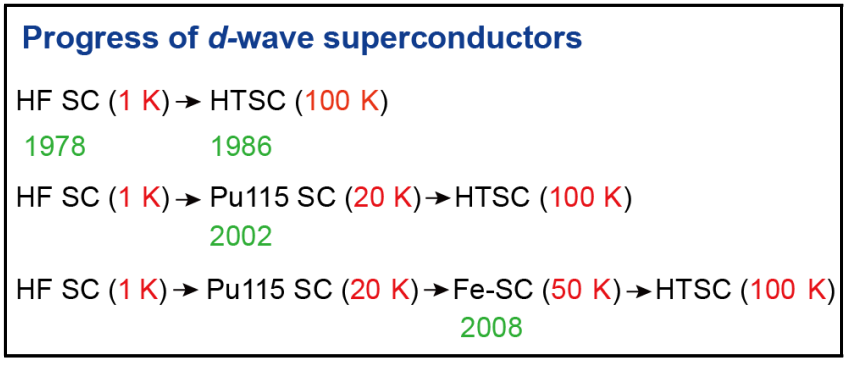

Fig. 9. History of representative $d$ wave superconductor discoveries.

여전히 $\pm s$-wave 갭 모델의 연속적인 변형에 의한 node(s)의 형성일 가능성이 매우 높다(그림 8 참조).

\section{3. 결론과 남은 문제들}

지금까지 설명한 바와 같이, 철-기반 초전도체의 쌍 대칭성은 $\pm s$-wave 갭임이 이론적으로나 실험적으로 거의 확실히 증명되 었다. 또한, 쌍 결합의 원인으로는 반강자성 요동의 스핀 요동 을 매개로 하는 반발력이 가장 유력한 후보이다. 마지막으로, 그림 7에서 보여주듯이, 이는 $d$-wave 초전도 쌍결합의 원인과 정확히 같은 원리이다. 이제, 초기에 언급하였듯이 우리가 알고 있는 표준적인 포논에 의해서 매개되는 $s$-wave 초전도체 이외 에 지난 30년간 발견된 non-phonon 초전도체는 한두 개의 $p$ -wave triplet 초전도체(예, $\mathrm{Sr}_{2} \mathrm{RuO}_{4}$ )를 제외하고는 모두 반강자 성 불안정성 근처에서 형성되는 $d$-wave 초전도체이다. 이제, 철-기반 초전도체의 $\pm s$-wave 갭을 쌍 결합 원리의 관점에서 $d$-wave 초전도체와 같은 범주로 분류한다면, 그림 9와 같은 도 표를 그릴 수 있다.

이로써, 우리는 반강자성 요동에 의해 매개되는 non-phononic 초전도체는 모두 $d$-wave 초전도체를 형성한다는 보편성 (Universality of the Unconventional Superconductivity)을 추 론할 수 있다. 앞으로 남은 문제는 크게 두 가지로 요약할 수 있 다. (1) 왜, 이러한 보편성(universality)이 형성되는가? (2) 이러 한, 보편성의 법칙에 따라서, 임계온도 $\left(T_{\mathrm{C}}\right)$ 를 더욱 증가시킬 수 있는 방법은 무엇인가? 이 두 가지 문제는 미래의 초전도 연구 의 가장 중요한 이슈이자 동력이다. 지난 5 년간의 철-기반 초전 도체의 발견과 연구의 가장 중요한 결실은 이러한 $d$-wave 초전 도체의 보편성 법칙에 결정적인 힌트를 준 것이라고 할 수 있다.

\section{REFERENCES}

[16] Y. Bang and H.-Y. Choi and H. Won, Phys. Rev. B 79, 054529 (2009).

[17] Y. Bang, Phys. Rev. Lett. 104, 217001 (2010).

[18] Y. Bang, Supercond. Sci. Technol. 25, 084002 (2012). 